Case Report

\title{
Allogeneic Hematopoietic Cell Transplantation for Therapy-Related Myeloid Leukemia following Orthotopic Cardiac Transplantation
}

\author{
Richard J. Lin, ${ }^{1}$ Richard A. Larson, ${ }^{2}$ Koen van Besien, ${ }^{1}$ and Elizabeth S. Rich \\ ${ }^{1}$ Department of Medicine, Weill Cornell Medical College, New York, NY 10065, USA \\ ${ }^{2}$ Section of Hematology/Oncology, Department of Medicine and the Cancer Research Center, University of Chicago, \\ Chicago, IL 60637, USA \\ ${ }^{3}$ Department of Medicine, Rush University Medical Center, 1725 W. Harrison Street, Ste 836, Chicago, IL 60612, USA
}

Correspondence should be addressed to Elizabeth S. Rich; elizabeth_s_rich@rush.edu

Received 19 February 2013; Accepted 14 March 2013

Academic Editors: D. J. Allsup, E. Bissé, K. Kawauchi, K. Khair, and P. Tsirigotis

Copyright (C) 2013 Richard J. Lin et al. This is an open access article distributed under the Creative Commons Attribution License, which permits unrestricted use, distribution, and reproduction in any medium, provided the original work is properly cited.

\begin{abstract}
Therapy-related myeloid neoplasm (t-MN) is a subtype of acute myeloid leukemia with adverse cytogenetics and poor overall prognosis despite intensive induction chemotherapy and allogeneic hematopoietic cell transplantation (allo-HCT). It is increasingly recognized as a late complication of chronic immunosuppression in patients who have received solid organ transplantation. In this paper, we describe a case of t-MN following orthotopic cardiac transplantation and its treatment with allo-HCT. We discuss molecular and biological challenges and considerations in double solid organ and bone marrow transplantation and review similar cases at our institution. Our experience suggests general feasibility and safety of allo-HCT in patients who have received solid organ transplantation.
\end{abstract}

\section{Case Presentation}

A 52-year-old Caucasian man with a history of hypertension and insulin-dependent type 2 diabetes mellitus underwent orthotopic cardiac transplantation for ischemic cardiomyopathy. Subsequent immunosuppression consisted of cyclosporine A (CsA), mycophenolate mofetil (MMF), and low dose prednisone. Four years later, he presented with a 3-week history of sinus congestion, fever, chills, and non-productive cough. Further workup showed leukocytosis of $137,000 / \mu \mathrm{L}$ with $31 \%$ blasts and $63 \%$ promonocytes, hemoglobin of $7.0 \mathrm{~g} / \mathrm{dL}$, platelets of $55,000 / \mu \mathrm{L}$, and acute kidney injury with creatinine of $3.3 \mathrm{mg} / \mathrm{dL}$. A bone marrow biopsy revealed monoblastic therapy-related myeloid neoplasm (t-MN). The karyotype was 46XY, inv(9)(p11q13)c, $\mathrm{t}(10 ; 11)(\mathrm{p} 11.2 ; \mathrm{q} 23)$ [100\%]. $\operatorname{Inv}(9)$ is a recognized human constitutional (c) polymorphism of unknown phenotypic significance while $\mathrm{t}(10 ; 11)$ is a recurring cytogenetic abnormality in acute myeloid leukemia [1]. There was no evidence of the FLT3 gene internal tandem deletion or D835 mutation, another common adverse prognostic factor in acute myeloid leukemia [1]. MMF was discontinued. CsA was changed to tacrolimus, and low dose prednisone was continued. The patient was initially treated with hydroxyurea for leukoreduction, and his hospital course was complicated by pulmonary hemorrhage requiring mechanical ventilation, tumor lysis syndrome, and complicated parapneumonic pleural effusion. He then underwent induction chemotherapy with high dose cytarabine $\left(2000 \mathrm{mg} / \mathrm{m}^{2}\right)$ and mitoxantrone $\left(20 \mathrm{mg} / \mathrm{m}^{2}\right)$. A morphologic and cytogenetic complete remission (CR1) was achieved three months later (Table 1).

Allogeneic hematopoietic cell transplantation (allo-HCT) was planned, as the patient's only sibling was an 8 of 8 HLA-match with the same ABO blood group A. Moreover, there were no anti-donor blood group antibodies in his serum. However, allo-HCT was delayed by vancomycinresistant enterococcus empyema that required thoracotomy with decortication. Cardiac biopsy at that time showed no evidence of acute rejection. Unfortunately, while recuperating from surgery, the patient's t-MN relapsed. He was treated 
TABLE 1: Clinical course and cytogenetic abnormalities of the patient.

\begin{tabular}{|c|c|c|c|c|c|c|}
\hline Time & 0 & 3 months & 6 months & 8 months & 12 months & 12 months \\
\hline Clinical course & $\begin{array}{c}\text { Acute } \\
\text { Leukemia }\end{array}$ & $\begin{array}{l}\text { Induction } \\
\text { chemo }\end{array}$ & Relapse & $\begin{array}{l}\text { Reinduction chemo + } \\
\text { allo-HCT }\end{array}$ & CNS relapse & Systemic relapse \\
\hline Treatment & Hydroxyurea & $\begin{array}{l}\text { Cytarabine + } \\
\text { mitoxantrone }\end{array}$ & & $\begin{array}{c}\text { Cytarabine }+ \\
\text { mitoxantrone }+ \\
\text { allo-HCT } \\
(\mathrm{Flu} / \mathrm{Mel} / \text { alemtuzumab })\end{array}$ & $\begin{array}{c}\text { Intrathecal } \\
\text { methotrexate }+ \\
\text { hydrocortisone; } \\
\text { cranial radiation }\end{array}$ & $\begin{array}{l}\text { Cytarabine + } \\
\text { Etoposide }\end{array}$ \\
\hline $\begin{array}{l}\text { Bone marrow } \\
\text { biopsy }\end{array}$ & $\begin{array}{l}\text { t-AML, } 91 \% \\
\text { blasts }\end{array}$ & CR1 & $\begin{array}{c}\text { Recurrent } \\
\text { t-AML, 53\% blasts }\end{array}$ & CR2 & & $\begin{array}{l}\text { Recurrent } \\
\text { t-AML, } \\
40 \% \text { blasts }\end{array}$ \\
\hline Karyotype & $\begin{array}{l}46 X Y, \operatorname{inv}(9) c \\
t(10 ; 11)\end{array}$ & $46 X Y, \operatorname{inv}(9) c$ & $\begin{array}{c}46 X Y, \operatorname{inv}(9) c, 20 \% ; 46 X Y \\
\operatorname{inv}(9) c, t(10 ; 11), 75 \%\end{array}$ & $46 \mathrm{XY}, 100 \%$ donor & & $\begin{array}{l}46 X Y, \operatorname{inv}(9) c \\
t(10 ; 11)\end{array}$ \\
\hline
\end{tabular}

TABLE 2: Post-solid organ transplant t-MNs at the University of Chicago.

\begin{tabular}{|c|c|c|c|c|c|}
\hline & Patient 1 & Patient 2 & Patient 3 & Patient 4 & Patient 5 \\
\hline Age/sex (years) & $57 / \mathrm{M}$ & $56 / \mathrm{M}$ & $50 / \mathrm{M}$ & $58 / \mathrm{F}$ & $55 / \mathrm{F}$ \\
\hline Organ transplant & Heart & Kidney & Heart & Liver & Kidney \\
\hline $\begin{array}{l}\text { Immuno-suppressive } \\
\text { therapy }\end{array}$ & $\begin{array}{c}\text { CsA } \\
\text { MMF } \\
\text { Prednisone }\end{array}$ & $\begin{array}{c}\text { CsA } \\
\text { MMF } \\
\text { Prednisone }\end{array}$ & $\begin{array}{l}\text { CsA } \\
\text { azathioprine } \\
\text { Prednisone }\end{array}$ & $\begin{array}{l}\text { CsA } \\
\text { azathioprine } \\
\text { Prednisone }\end{array}$ & $\begin{array}{l}\text { Cytoxan } \\
\text { Prednisone }\end{array}$ \\
\hline Latency (years) & 4.3 & 4.4 & 12.3 & 7.7 & 7 \\
\hline WHO classification & $\mathrm{t}-\mathrm{AML}$ & $\mathrm{t}-\mathrm{AML}$ & $\mathrm{t}-\mathrm{MDS}$ & t-MDS & $\mathrm{t}-\mathrm{MDS}$ \\
\hline Treatment & $\begin{array}{c}\text { Induction chemo + } \\
\text { allo-HCT }\end{array}$ & $\begin{array}{c}\text { Induction chemo + } \\
\text { allo-HCT }\end{array}$ & $\begin{array}{c}\text { Induction chemo + } \\
\text { auto-HCT }\end{array}$ & Induction chemo & Supportive care \\
\hline Survival (years) & 1 & 1.5 & 3.6 & 1.3 & 1.9 \\
\hline Karyotype & $46 X Y, \operatorname{inv}(9) c, t(10 ; 11)$ & Normal & $\begin{array}{c}\text { 46XY, 55\%; 46XY, } \\
\text { del 7, 25\%; 46XY, } \\
\text { del 11, } 20 \%\end{array}$ & Normal & $\begin{array}{c}\text { 46XX, 55\%; 46XX, } \\
\operatorname{inv}(9) c \text {, del 7, 41\%; } \\
46 X X, \operatorname{inv}(9) c, \text { del 19, 4\% }\end{array}$ \\
\hline
\end{tabular}

again with high dose cytarabine $\left(2000 \mathrm{mg} / \mathrm{m}^{2}\right)$ and mitoxantrone $\left(20 \mathrm{mg} / \mathrm{m}^{2}\right)$. At day 13 bone marrow biopsy showed a severely hypocellular marrow (3\%) with scattered residual blasts (10-15\%). The patient underwent a non-myeloablative allo-HCT following conditioning with fludarabine, melphalan, and alemtuzumab 8 months after the diagnosis of t-MN [2]. His post-transplant course was uncomplicated; myeloid cells engrafted by day +13 and platelets by day +27 . $\mathrm{He}$ continued to receive tacrolimus and low dose prednisone for immunosuppression of his cardiac graft. On day +27 , engraftment analysis revealed that donor DNA accounted for $>95 \%$ of total DNA in the unfractionated marrow sample and $88( \pm 3) \%$ of DNA in the CD3(+) population. On day +145 , a complete morphologic and cytogenetic remission (CR2) was documented. There were no signs of rejection of the patient's cardiac graft, and his cardiac function remained normal with a left ventricular ejection fraction of $59 \%$. However, 4 months after allo-HCT, the patient presented with diplopia and was found to have central nervous system relapse of t-MN. He underwent intrathecal chemotherapy and whole brain radiation therapy with symptomatic improvement. Systemic chemotherapy with cytarabine and etoposide was started, but the patient's hospital course was complicated by sepsis, and he died from multi-organ failure (Table 1).

\section{Discussion}

Non-Hodgkin lymphoma is the most common malignancy that occurs after solid organ transplantation $[3,4]$, but t-MN has also been described [5-8]. T-MN generally portends a poor prognosis despite treatment with induction chemotherapy and, more recently, allo-HCT [9]. Treatment of t-MN in solid organ transplant recipients is even more challenging as these patients require ongoing immunosuppression and often have multiple co-morbidities. This patient's treatment course illustrates several important issues in considering alloHCT for t-MN following solid organ transplantation and in conducting post-transplant care.

First, the patient's cadaveric cardiac graft was an 8 of 8 HLA-mismatch with the patient, initially raising the question of whether allo-HCT might result in rejection of the patient's transplanted heart. Fortunately, his sibling donor was a full HLA-match as well as ABO-compatible, the major determinant in cardiac transplant, thus reducing the risk of rejecting the patient's cardiac graft. Second, we screened the recipient's serum and found no preformed HLA antibodies against the transplanted heart. A right heart biopsy was negative for acute cellular rejection, and a C4d stain of the biopsy, a marker for allograft rejection, was also negative. 
Finally, although there was the potential for a T-cell mediated immune response by the stem cell donor's lymphocytes against the previously transplanted heart, we saw no sign of this during the peri-transplant period. A literature search found several previous case reports of HCT in recipients of cardiac transplantation [10-13]. All but one patient survived HCT without rejecting their cardiac graft. However, the peritransplant mortality and morbidity was high, reflecting the fine balance between risks of serious infections and the need for ongoing immunosuppression [10-13].

Interestingly, t-MN is increasingly observed in patients receiving long-term immunosuppression for both solid organ transplants and chronic inflammatory diseases [14]. Immunosuppressants such as CsA and MMF have been implicated, and the use of azathioprine has been postulated to affect the host cell's DNA mismatch repair system leading to $\mathrm{t}-\mathrm{MN}[14]$. A review of the $\mathrm{t}-\mathrm{MN}$ database at the University of Chicago identified five patients who developed t-MN after solid organ transplantation (Table 2). The median age was 56 years (range, 50-58); median latency following transplantation was 7 years (range, 4.3-12.3); and median survival from diagnosis of t-MN was 1.5 years (range, 1-3.6). Four of five patients received CsA, two received MMF, and two received azathioprine. Karyotype was normal in two patients, del(7q) in two patients, and $t(10 ; 11)$ in the last patient. $\operatorname{Del}(7 q)$ and $\mathrm{t}(10 ; 11)$ are two recurring, poor-risk cytogenetic abnormalities observed in t-MN [9]. Three of five patients, including the patient presented here, underwent HCT (2 allogeneic and 1 autologous) without rejecting transplanted solid organs. Overall, our experience suggests that HCT may be performed safely to treat $\mathrm{t}-\mathrm{MN}$ developing in solid organ transplant recipients receiving concurrent immunosuppressants.

\section{Conflict of Interests}

The authors declare no conflict of interests.

\section{Acknowledgments}

The authors gratefully acknowledge Dr. Susana Marino for helpful discussions, Dr. Yanming Zhang for cytogenetic analyses, and Dr. Loren Joseph for engraftment analyses.

\section{References}

[1] E. H. Estey, "Acute myeloid leukemia: 2012 update on diagnosis, risk stratification, and management," The American Journal of Hematology, vol. 87, no. 1, pp. 89-99, 2012.

[2] K. van Besien, A. Artz, S. Smith et al., "Fludarabine, melphalan, and alemtuzumab conditioning in adults with standard-risk advanced acute myeloid leukemia and myelodysplastic syndrome," Journal of Clinical Oncology, vol. 23, no. 24, pp. 57285738, 2005.

[3] I. Penn, "Incidence and treatment of neoplasia after transplantation," Journal of Heart and Lung Transplantation, vol. 12, no. 6, part 2, pp. S328-S336, 1993.

[4] K. A. Engels, R. M. Pfeiffer, J. F. Fraumeni et al., "Spectrum of cancer risk among US solid organ transplant recipients," The
Journal of the American Medical Association, vol. 306, no. 17, pp. 1891-1901, 2011.

[5] R. Thalhammer-Scherrer, G. Wieselthaler, P. Knoebl et al., "Post-transplant acute myeloid leukemia (PT-AML)," Leukemia, vol. 13, no. 3, pp. 321-326, 1999.

[6] J. Offman, G. Opelz, B. Doehler et al., "Defective DNA mismatch repair in acute myeloid leukemia/myelodysplastic syndrome after organ transplantation," Blood, vol. 104, no. 3, pp. 822-828, 2004.

[7] M. Camós, J. Esteve, A. Rimola et al., "Increased incidence of acute myeloid leukemia after liver transplantation? Description of three new cases and review of the literature," Transplantation, vol. 77, no. 2, pp. 311-313, 2004.

[8] M. Menes, E. Vakiani, C. E. Keller et al., "The spectrum of myelodysplastic syndromes post-solid organ transplantation: a single institutional experience," Leukemia Research, vol. 31, no. 1, pp. 59-65, 2007.

[9] L. A. Godley and R. A. Larson, "Therapy-related myeloid leukemia," Seminars in Oncology, vol. 35, no. 4, pp. 418-429, 2008.

[10] J. Lister, J. K. Simpson, M. M. deMagalhaes-Silverman et al., "Allogeneic peripheral blood stem cell transplant for myelodysplasia after chemotherapy for post-transplant lymphoma in a cardiac transplant recipient at 10 years," Bone Marrow Transplantation, vol. 19, no. 9, pp. 943-945, 1997.

[11] G. Huebner, M. Karthaus, K. Pethig, M. Freund, and A. Ganser, "Myelodysplastic syndrome and acute myelogenous leukemia secondary to heart transplantation," Transplantation, vol. 70, no. 4, pp. 688-690, 2000.

[12] G. Kobbe, U. Germing, M. Aivado et al., "Treatment of secondary myelodysplastic syndrome after heart transplantation with chemotherapy and nonmyeloablative stem-cell transplantation," Transplantation, vol. 74, no. 8, pp. 1198-1200, 2002.

[13] T. Schechter, A. Gassas, S. Weitzman et al., "Hematopoietic stem-cell transplantation following solid-organ transplantation in children," Bone Marrow Transplantation, vol. 46, no. 10, pp. 1321-1325, 2011.

[14] S. M. Ramadan, T. M. Fouad, V. Summa, S. K. H. Hasan, and F. Lo-Coco, "Acute myeloid leukemia developing in patients with autoimmune diseases," Haematologica, vol. 97, no. 6, pp. 805817,2012 


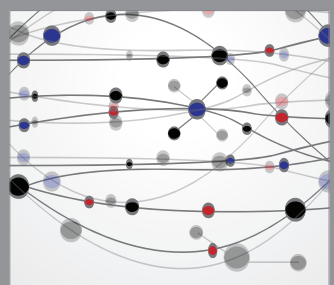

The Scientific World Journal
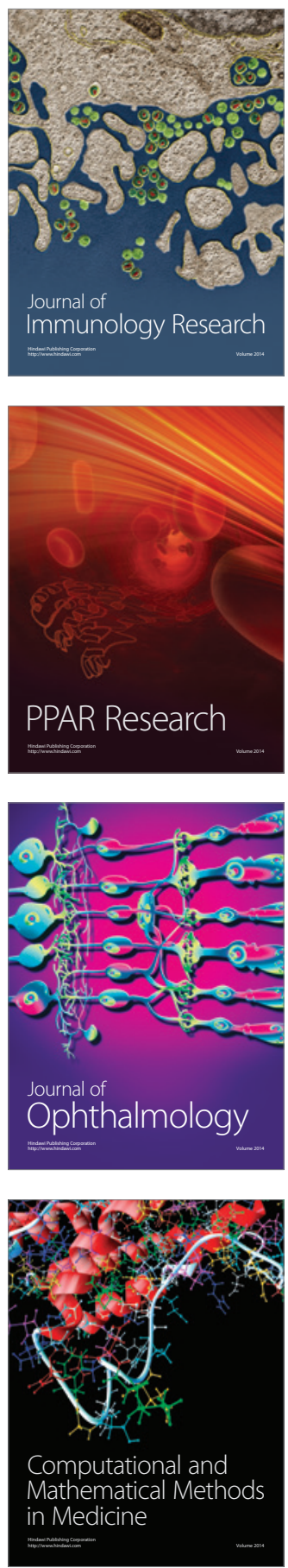

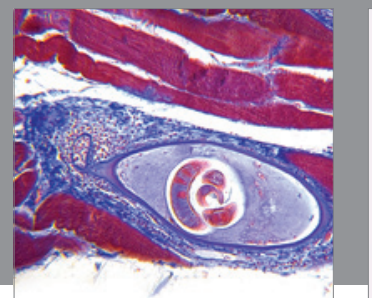

Gastroenterology

Research and Practice
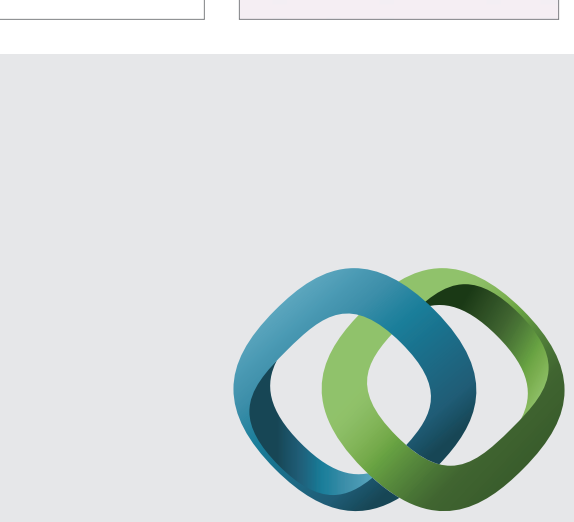

\section{Hindawi}

Submit your manuscripts at

http://www.hindawi.com
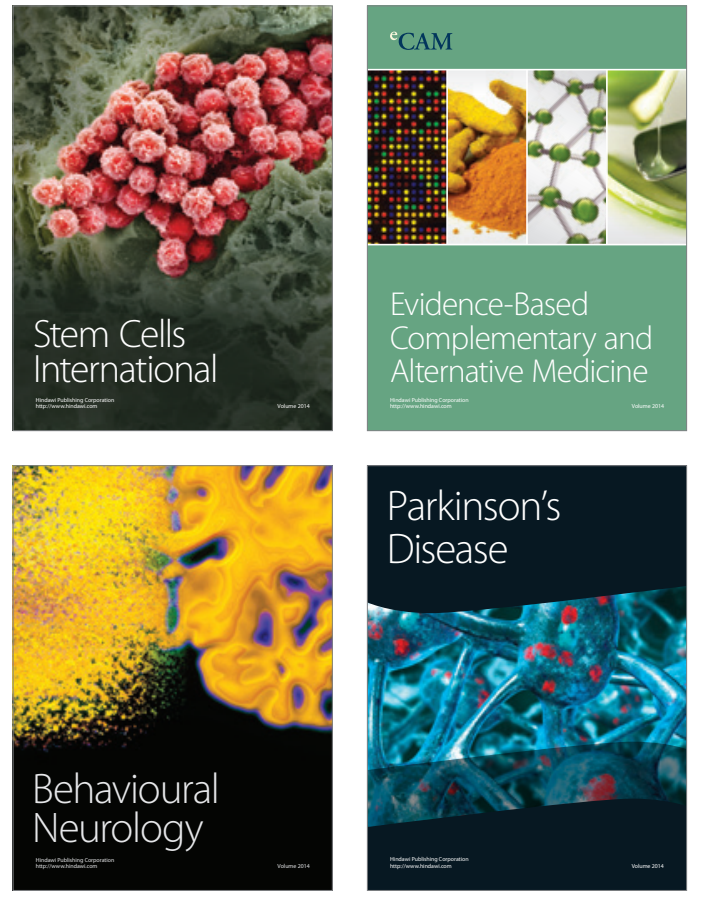
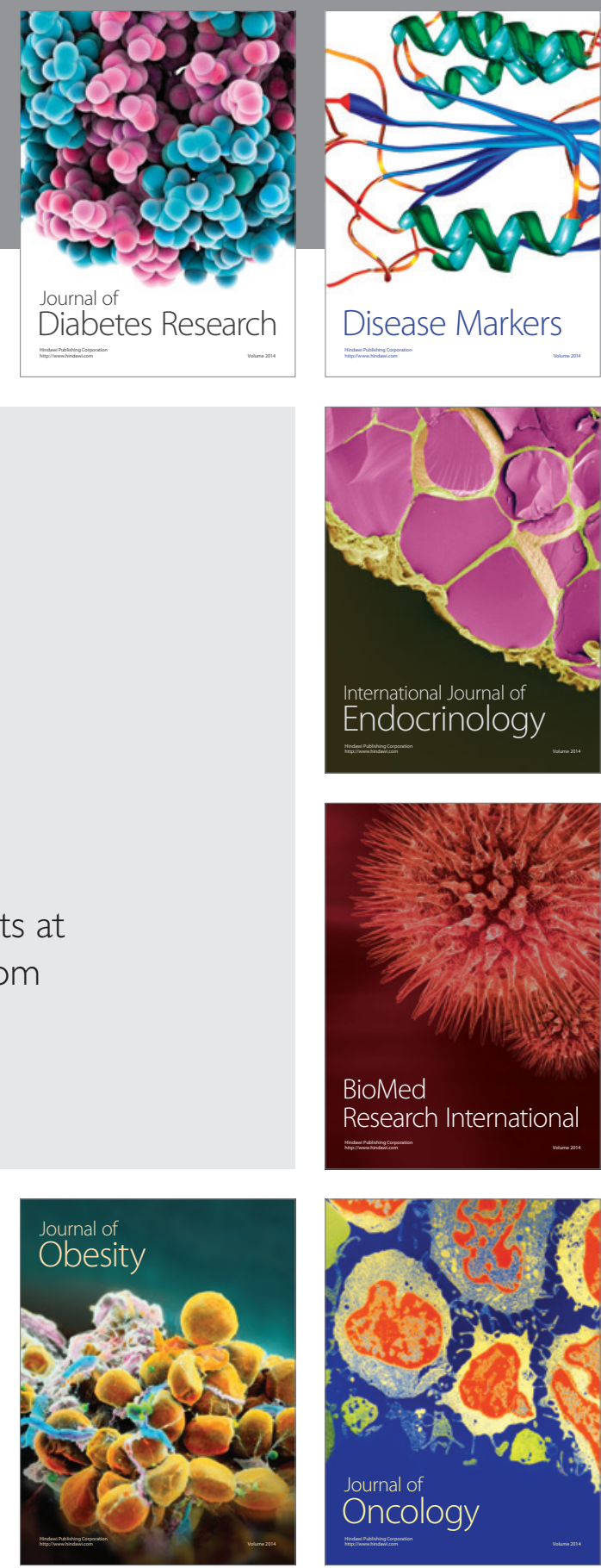

Disease Markers
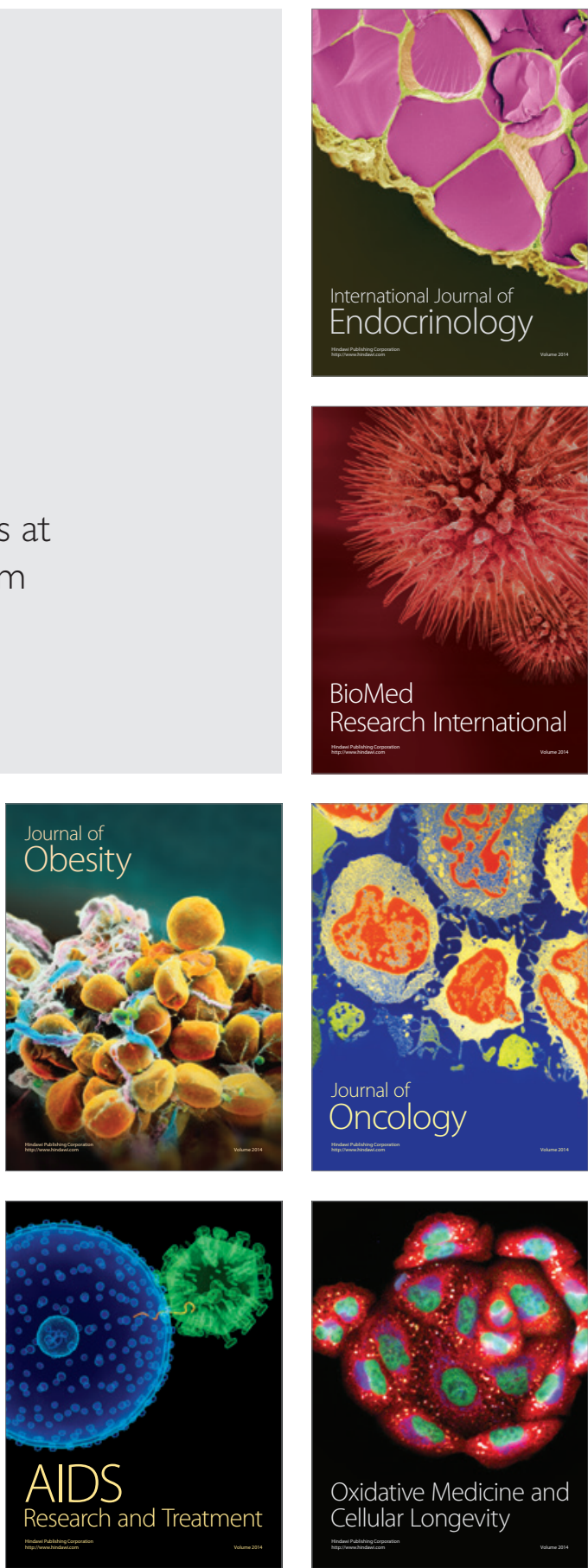